\title{
Keanekaragaman Vegetasi Agroekosistem Karet Masyarakat Dayak Kerabat di Desa Nanga Pemubuh Kecamatan Sekadau Hulu Kabupaten Sekadau
}

\author{
Agustinus Harmono ${ }^{1}, \operatorname{Rafdinal}^{1}, \operatorname{Riza}_{\operatorname{Linda}^{1}}$ \\ ${ }^{1}$ Program Studi Biologi, Fakultas MIPA, Universitas Tanjungpura, JL. Prof. Dr. H. Hadari Nawawi, Pontianak \\ email korespondensi: idharmono@gmail.com
}

\begin{abstract}
The agroecosystem is an ecological system that exists within the agricultural environment and one of the natural systems that occur after it is formed by the human. The Dayak people plant local rubber and are left to grow without intensive care along with various types of pioneering plants, fruit trees and woody trees. The aim of the study is to determine the composition and vegetation. The method used in this study is purposive sampling. The results are that there are 36 species consisting of 33 genera and 23 families. Generally, there are 16 tree species, 17 pole species, 18 stake species, and 16 seedling species. The most dominant families in the Nanga Pemubuh Village in all growth rates comprise 3 families, namely Arecaceae, Dipterocaearpace, and Moraceae with each number including 4 types of vegetation. The diversity of vegetation species of rubber agroecosystem is rated as medium or stable values $\left(\mathrm{H}^{\prime}\right.$ tree $=2,339, \mathrm{H}^{\prime}$ pole $=2,294$, and $\mathrm{H}^{\prime}$ stake $=1,652$ ). Uniformity of the vegetation species of rubber agroecosystem is relatively high $0.794-0.941$ and there is no dominance $(\mathrm{C})$ in all growth rates $0.107-0.224$.
\end{abstract}

Keywords: Diversity, Vegetation, Agroecosystem

\section{PENDAHULUAN}

Kalimantan Barat memiliki bentang alam cukup beragam, mulai dari ekosistem daratan hingga ekosistem perairan. Kondisi alam yang beragam menjadi faktor pendukung tingginya keanekaragaman hayati yang ada di Kalimantan Barat (Iyai \& Pattiselano, 2006). Ekosistem ini dimodifikasi dan dimanfaatkan secara langsung atau tidak langsung oleh manusia untuk memenuhi kebutuhan atas pangan dan serat-seratan sehingga membentuk ekosistem baru yang disebut agroekosistem (KEPAS, 1998).

Masyarakat Dayak menanam karet lokal dan dibiarkan tumbuh tanpa perawatan intensif bersama dengan berbagai jenis tumbuhan pioner, pohon buah dan pohon berkayu. Apabila tanaman karet lokal ini sudah tidak produktif dan banyak yang mati maka tumbuhan pohon buah dan pohon berkayu akan menggantikan tanaman karet tersebut. Pada tahap ini maka kawasan tumbuhan karet tersebut beralih menjadi hutan dan dikenal sebagai tembawang. Semakin lama kawasan agroekosistem karet akan semakin mirip struktur dan komposisinya dengan hutan alam, serta memiliki keanekaragaman jenis tumbuhan yang beragam (Arifin et al., 2003)

Kawasan agroekosistem karet di Desa Nanga Pemubuh Kabupaten Sekadau dibudidayakan secara turun temurun oleh masyarakat Dayak Kerabat. Kawasan agroekosistem karet tradisional ini berasal dari karet lokal di Nanga Pemubuh yang ditanam di kawasan sekitar desa. Vegetasi yang ada di kawasan agroekosistem ini masih beragam. Kuni et al., (2015), menemukan sebanyak 185 jenis dari 70 familiyang dimanfaatkan masyarakat Dayak Kerabat di kawasan hutan Desa Tapang Perodah, Kabupaten Sekadau.

Berdasarkan hasil penelitian terdahulu ditemukan jenis vegetasi penyusun agroekosistem. Rafdinal \& Pitopang (2019) menemukan 43 spesies, 32 genus dan 13 famili pada tingkat pohon di agroekosistem tembawang di Sekadau Hulu. Sementara itu Sumarhani dan Kalima (2015) menemukan penyusun agroekosistem tembawang di Desa Cempedak sebagian besar adalah hasil hutan bukan kayu seperti jenis tanaman penghasil buah, tanaman penghasil kayu, dan tanaman penghasil getah.Ripin et al (2015) menemukan jenis vegetasi penyusun yang dominan pada agroekosistem tembawang di Kabupaten Sanggau adalah tanaman karet lokal (Hevea brasilliesis).

Penelitian mengenai keanekaragaman vegetasi pada kawasan agroekosistem karet di Nanga Pemubuh belum pernah dilakukan sehinga perlu dilakukan penelitian tentang keanekaragaman jenis 
vegetasi pada kawasan agroekosistem karet masyarakat Dayak Kerabat di Desa Nanga Pemubuh Kecamatan Sekadau Hulu Kabupaten Sekadau. Tujuan penelitian adalah mengetahui komposisi dan keanekaragaman jenis vegetasi yang ada di kawasan agroekosistem karet di desa Nanga Pemubuh.

\section{BAHAN DAN METODE}

\section{Waktu dan Tempat Penelitian}

Penelitian ini akan dilaksanakan selama 4 bulan yaitu pada bulan Oktober-Desember 2017 di Desa Nanga Pemubuh. Tahapan penelitian ini adalah survei lokasi penelitian, persiapan alat dan bahan, sampling, identifikasi dan pengolahan data. Identifikasi tumbuhan dilakukan di Laboratorium Biologi Fakultas Matematika dan Ilmu Pengetahuan Alam Universitas Tanjungpura Pontianak.

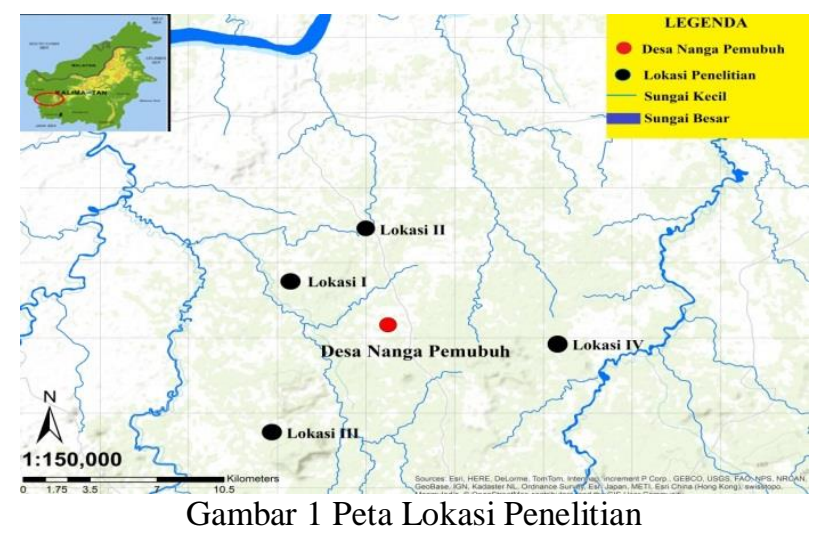

\section{Alat dan Bahan}

Alat yang digunakan dalam penelitian ini adalah GPS (Global Positioning Syestem), kamera, tali raffia, pancang, plastik, termometer, soil $\mathrm{pH}$ tester, altimeter, lux meter, hygrometer, dan kompas.

\section{Metode Penelitian}

\section{Penentuan Lokasi Sampling}

Metode yang digunakan dalam penentuan lokasi sampling penelitian adalah metode purposive sampling (Fachrul, 2006). Pengambilan sampel dilakukan di Desa Nanga Pemubuh yaitu di kawasan agroekosistem karet yang dibedakan berdasarkan 4 kriteria lokasi sebagai berikut:

a. Agrosistem karet di Dusum Emperarak (lokasi I)

b. Agrosistem karet di Dusun Sepanjang(lokasi II)

c. Agrosistem karet di Natai Ilong (lokasi III)

d. Agrosistem karet di Tembawang Hangus (lokasi IV)

Pengamatan Keanekaragaman Vegetasi
Metode yang digunakan dalam penelitian ini adalah metode garis berpetak dengan kombinasi jalur. Petak-petak pada cara garis berpetak ini dapat berbentuk persegi panjang, bujur sangkar atau lingkaran (Soerianegara \& Indrawan, 1988). Dalam penelitian ini bentuk yang digunakan adalah persegi panjang.

Ukuran tiap petak (plot) pengamatan $20 \mathrm{~m}$ x $20 \mathrm{~m}$ masing-masing petak pengamatan dibuat plot dengan ukuran $2 \mathrm{~m} \times 2 \mathrm{~m}$ untuk tingkat semai, $5 \mathrm{~m}$ x $5 \mathrm{~m}$ untuk tingkat pancang, $10 \mathrm{~m}$ x $10 \mathrm{~m}$ untuk tingkat tiang, dan $20 \mathrm{~m} \times 20 \mathrm{~m}$ untuk tingkat pohon (Suin, 2002).

\section{Pengukuran Faktor Lingkungan}

Pengukuran faktor lingkungan dilakukan bersamaan dengan pengamatan keanekaragaman vegetasi tumbuhan yaitu meliputi pengukuran suhu dengan menggunakan thermometer, kelembaban tanah dan udara dengan hygrometer, $\mathrm{pH}$ tanah menggunakan soil $\mathrm{pH}$ tester, dan intensitas cahaya dengan lux meter.

\section{Identifikasi Jenis Tumbuhan}

Identifikasi jenis tumbuhan menggunakan buku Flora (Steenis, 2005) dan buku Identifikasi Tumbuhan Tingkat Tinggi (Dasuki, 1991). Identifikasi ini dilakukan langsung di lapangan dan apabila belum diketahui jenis tumbuhannya maka akan dilanjutkan di Laboratorium Biologi Fakultas Matematika dan Ilmu Pengetahuan Alam.

\section{Analisis Data}

Data yang diperoleh kemudian digunakan untuk menganalisis komposisi jenis yang meliputi:

Analisis komposisi jenis agroekosistem karet meliputi:

$$
\begin{aligned}
& K=\frac{\text { Jumlah Individu suatu jenis }}{\text { Luas plot }} \\
& K R=\frac{\text { Kepadatan suatu jenis }}{\text { Kepadatan seluruh jenis }} \times 100 \% \\
& F=\frac{\text { jumlah plot ditemukan suatu jenis }}{\text { jumlah seluruh jenis }} \\
& F R=\frac{\text { Frekuensi suatu jenis }}{\text { Frekuensi seluruh jenis }} \times 100 \% \\
& D=\frac{\text { Jumlah luas bidang dasar suatu jenis }}{\text { Luas plot }} \\
& \mathrm{DR}=\frac{\text { Dominansi suatu jenis }}{\text { Dominansi seluruh jenis }} \times 100 \%
\end{aligned}
$$

\footnotetext{
Keterangan :

$\mathrm{K}$ = Kerapatan

$\mathrm{KR}=$ Kerapatan relatif

$\mathrm{F}=$ Frekuensi

FR $=$ Frekuensi relatif
} 
$\mathrm{D}=$ Dominansi

$\mathrm{DR}=$ Dominansi relatif

Selanjutnya ditemukan Indeks Nilai Penting (INP) dengan menggunakan rumus:

1) Untuk tingkat pohon $\mathrm{INP}=\mathrm{KR}+\mathrm{FR}+\mathrm{DR}(\geq 10 \%$, INP tinggi $)$

2) Untuk tingkat tiang, pancang, dan semai $\mathrm{INP}=\mathrm{KR}+\mathrm{FR}(\geq 10 \%$, INP tinggi $)$

Keterangan

INP = Indeks Nilai Penting

Semakin besar nilai INP maka semakin tinggi tingkat penguasaan jenis dalam komunitas tesebut (Suin, 2002).

Analisis keanekaragaman vegetasi agroekosistem karet dilakukan dengan menggunakan indeks meliputi:

1) Indeks Dominansi (C)

Indeks dominansi digunakan untuk menentukan dominansi suatu jenis dalam suatu komunitas dapat dihitung dengan rumus sebagai berikut:

$$
\mathrm{C}=\sum\left[\frac{n i}{N}\right]^{2}
$$

Keterangan:

$\mathrm{C}=$ Indeks dominansi

ni $=$ Indek nilai penting dari spesies ke-1

$\mathrm{N}=$ Total indeks nilai penting

2) Indeks Keanekaragaman (H')

Hasil indeks keanekaragaman (H') digunakan untuk menentukan jeniss-jenis tegakan menggunakan rumus Shannon Of Diversity (Odum, 1993) sebagai berikut:

$$
\mathrm{H}^{\prime}=-\sum\left[\frac{n i}{N}\right] \ln \left[\frac{n i}{N}\right]
$$

Keterangan:
H'= Indeks keanekaragaman jenis

ni $=$ Indeks nilai penting jenis

$\mathrm{N}=$ Total indeks nilai penting

Hasil yang diperoleh dihubungkan dengan kategori indeks keragaman sebagai berikut:

Tabel 1. Klasifikasi Tingkat Keanekaragaman

\begin{tabular}{ccc}
\hline No & Tingkat Keanekaragaman & Nilai \\
\hline 1 & Rendah & $<1,5$ \\
2 & Sedang & $1,5-3,5$ \\
3 & Tinggi & $>3,5$ \\
\hline
\end{tabular}

Sumber: Odum, 1993

3) Indeks Kemerataan Jenis (E')

Menurut Odum (1993), kategori Indeks Kemerataan Jenis (E') berkisar antara 0 sampai 1. Jika E'>1, maka penyebaran jenis merata dan jika $\mathrm{E}^{\prime}<1$, maka sebaran jenisnya tidak merata.

$$
\mathrm{E}^{\prime}=\frac{H^{\prime}}{\operatorname{Ln} S}
$$

Keterangan:

$\mathrm{E}^{\prime}=$ Indeks kemerataan jenis

$\mathrm{H}^{\prime}=$ Indeks Keanekaragaman

$\mathrm{S}=$ Jumlah jenis

\section{HASIL DAN PEMBAHASAN}

\section{Hasil}

\section{Komposisi dan Struktur Jenis Vegetasi}

Berdasarkan penelitian yang dilakukan di Desa Nanga Pemubuh Kecamatan Sekadau Hulu Kabupaten Sekadau, ditemukan hasil sebagai berikut :

Tabel 2. Komposisi Jenis Tegakan Vegetasi di Kawasan Agroekosistem Karet

\begin{tabular}{lcccc}
\hline Karakteristik & \multicolumn{4}{c}{ Lokasi } \\
\cline { 2 - 4 } & 1 & 2 & 3 & 4 \\
\hline Jumlah jenis & 16 & 19 & 12 & 5 \\
Jumlah genus & 14 & 16 & 10 & 5 \\
Jumlah family & 10 & 12 & 8 & 4 \\
\hline
\end{tabular}

Keterangan : Lokasi 1 (Dusun Emperarak); Lokasi 2 (Dusun Sepanjang); Lokasi 3 (Kawasan Dusun Natai Ilong); Lokasi 4 (Tembawang Hangus)

Berdasarkan Tabel 2 komposisi jenis tegakan yang ditemukan di Desa Nanga Pemubuh, Kecamatan Sekadau Hulu, Kabupaten Sekadau didapatkan 16 jenis tegakan pada lokasi Dusun Emperarak yang terdiri dari 14 genus dan 10 famili. Sedangkan di lokasi Dusun Sepanjang ditemukan 19 jenis tegakan yang terdiri dari 16 genus dan 12 famili yang. Lokasi Dusun Natai Ilong ditemukan 12 jenis tegakan yang terdiri dari 10 genus dan 8 famili
Lokasi Tembawang Hangus ditemukan 5 jenis, 5 genus dan 4 spesies. Komposisi tingkat tegakan tertinggi yaitu pada tingkat pancang kemudian pada tingkat tiang, lalu tingkat pohon dan semai. Secara keseluruhan ditemukan yaitu tingkat pohon 16 jenis, tiang 17 jenis, pancang 18 jenis, dan semai 16 jenis. Gambaran lengkap dapat dilihat pada Gambar 2 


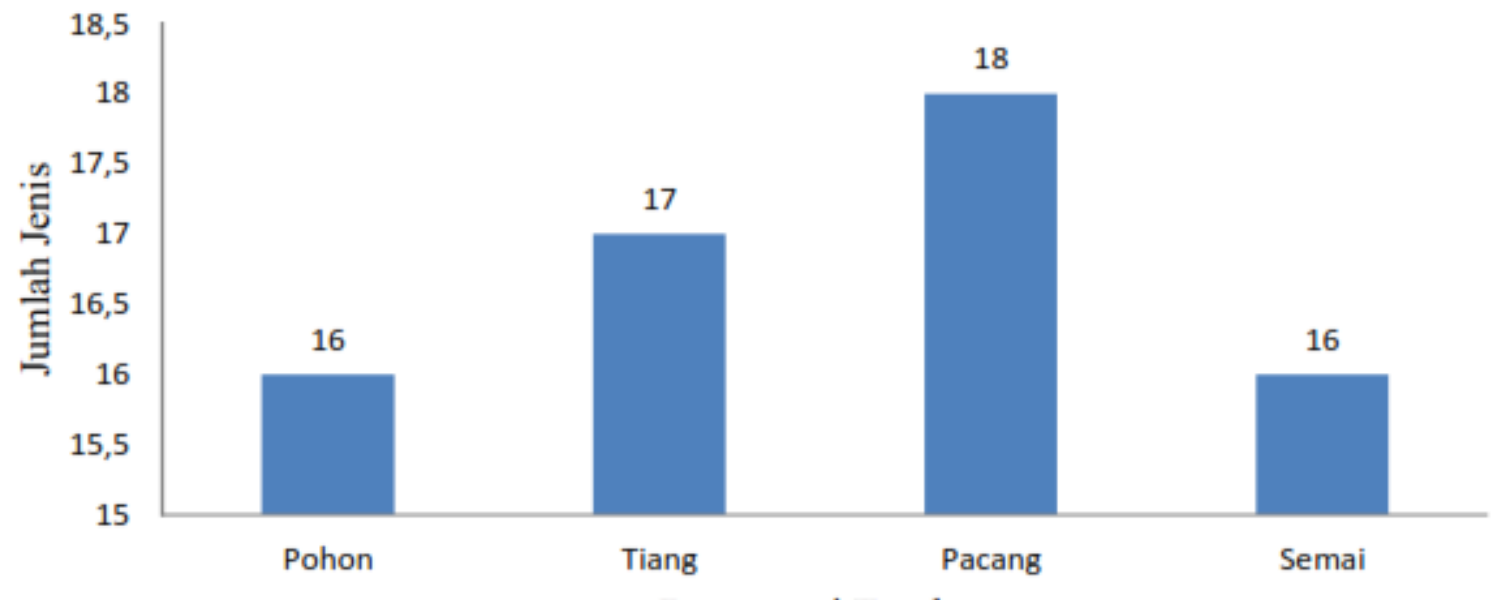

Regenerasi Tegakan

Gambar 2 Komposisi jenis berdasarkan regenerasi tegakan

Berdasarkan hasil analisis dari penelitian di kawasan agroekosistem karet di Desa Nanga Pemubuh ditemukan sebanyak 36 spesies, 33 genus dan 23 famili. Famili yang memiliki jenis terbanyak pada lokasi penelitian di kawasan agroekosistem karet di Desa Nanga Pemubuh terdiri dari 3 famili yaitu famili Arecaceae, Dipterocaearpace, dan Moraceae dengan jumlah masing-masing 4 jenis. Arecaceae dengan jumlah 4 jenis yaitu Areca catechu, Arenga pinnata,
Calamus sp. dan Korthalsia flagellaris. Famili Dipterocaearpace terdiri dari 4 jenis yaitu Shorea bracteolata, Shorea leprosula, Shorea macrophylla, dan Hopea sangal. Kemudian famili Moraceae terdiri dari 4 jenis yaitu Artocarpus anisophyllus, Artocarpus elasticus, Artocarpus integer, dan Ficus sp. Berdasarkan dari hasil penelitian menurut genus dan famili yang ditemukan ada yang sama dan ada yang berbeda pada tiap-tiap lokasi pengamatan (Tabel 3).

Tabel 3. Jumlah Spesies, Genus, dan Nama Lokal Vegetasi Agroekosistem Karet Berdasarkan Famili Vegetasi yang Ditemukan di Kawasan Desa Nanga Pemubuh

\begin{tabular}{|c|c|c|c|}
\hline Famili & Genus & Nama Spesies & Nama Daerah \\
\hline 1 Anacardiaceae & Mangifera & Mangifera minor & Keni \\
\hline 2 Apocynace & Alstoni & Alstonia scholaris & Pelaik \\
\hline \multirow[t]{4}{*}{3 Arecaceae } & Areca & Areca catechu & Pinang \\
\hline & Arenga & Arenga pinnata & Bungo utan \\
\hline & Korthalsia & Korthalsia flagellaris & Ui maro \\
\hline & Calamus & Calamus sp. & Ui kocit \\
\hline 4 Asparagaceae & Dracaena & Dracaena sp. & Bungo utan \\
\hline 5 Aspleniaceae & Asplenium & Asplenium sp. & Rajang tanah \\
\hline 6 Bromeliaceae & Cryptanthus & Cryptanthus acaulis & Bungo utan \\
\hline 7 Cannaceae & Canna & Canna sp. & Bomban \\
\hline 8 Clusiaceae & Garcinia & Garcinia parvifolia & Gandis \\
\hline 9 Cyperaceae & Cyperus & Cyperus sp. & Bung utan \\
\hline 10 Dilleniaceae & Dillenia & Dillenia indica & Simpor \\
\hline \multirow{4}{*}{11 Dipterocaearpace } & Shorea & Shorea bracteolata & Loban \\
\hline & & Shorea leprosula & Abu-abu \\
\hline & & Shorea macrophylla & Engkabang \\
\hline & Hopea & Hopea sangal & Teladan \\
\hline \multirow[t]{2}{*}{12 Euphorbiaceae } & Hevea & Hevea brasilliensis & Nyatuk/gotok \\
\hline & Macaranga & Macaranga tanarius & Bongkan \\
\hline \multirow[t]{3}{*}{13 Fabaceae } & Archidendron & Archidendron pauciflorum & Jorin \\
\hline & Parkia & Parkia speciosa & Pote \\
\hline & Durio & Durio zibethinus & Derian \\
\hline 14 Malvaceae & Bellucia & Bellucia axinanthera & Jambu korok \\
\hline
\end{tabular}


Tabel 3. Jumlah Spesies, Genus, dan Nama Lokal Vegetasi Agroekosistem Karet Berdasarkan Famili Vegetasi yang Ditemukan di Kawasan Desa Nanga Pemubuh

\begin{tabular}{|c|c|c|c|c|}
\hline \multicolumn{2}{|c|}{ Famili } & Genus & Nama Spesies & Nama Daerah \\
\hline & Moraceae & Lansium & Artocarpus anisophyllus & Entawo \\
\hline & & Artocarpus & Artocarpus elasticus & Pluntan \\
\hline & & & Artocarpus integer & Tebodak \\
\hline 16 & Myrtaceae & Ficus & Ficus sp. & Jengkal \\
\hline 17 & Orchidaecae & Syzygium & Syzygium malaccense & Bungo utan \\
\hline 18 & Phyllanthaceae & Spathoglottis & Spathoglottis sp. & Bungo utan \\
\hline 19 & Poaceae & Phylanthus & Phylanthus niruri & Sekandik \\
\hline 20 & Pteridaceae & Bambusa & Bambusa tuldoides & Muntik \\
\hline \multirow[t]{2}{*}{21} & Sapindaceae & Pteris & Pteris sp. & Semolik \\
\hline & & Dimocarpus & Dimocarpus longan & Engkuis \\
\hline 22 & Simaroubaceae & Nephelium & Nephelium lappaceum & Beletek \\
\hline \multirow[t]{2}{*}{23} & Zingiberaceae & Eurycoma & Eurycoma longifolia & Kemobar \\
\hline & & Aтотит & Amomum compactum & Sumpak \\
\hline Jun & lah 23 & 33 & 36 & 36 \\
\hline
\end{tabular}

Komposisi jenis pada tingkat pohon ada 16 spesies dengan total 70 individu. Nilai kerapatan tertinggi yaitu Durio zibethinus (15 ind/ha), kemudian Hevea braziliensis (11,25 ind/ha), Artocarpus integer dan
Dimocarpus longan, masing-masing memliki nilai kerapatan 7,5 ind/ha. Nilai dominansi tertinggi yaitu pada Hevea braziliensis dengan nilai dominansi adalah $1,716 \mathrm{~m}^{2} /$ ha (Tabel 4 ).

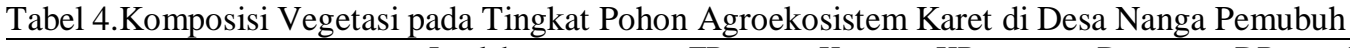

\begin{tabular}{lcccccccc}
\multicolumn{1}{c}{ Spesies } & $\begin{array}{c}\text { Jumlah } \\
\text { individu }\end{array}$ & $\mathrm{F}$ & $\begin{array}{c}\mathrm{FR} \\
(\%)\end{array}$ & $\begin{array}{c}\mathrm{K} \\
(\mathrm{ind} / \mathrm{ha})\end{array}$ & $\begin{array}{c}\mathrm{KR} \\
(\%)\end{array}$ & $\begin{array}{c}\mathrm{D} \\
\left(\mathrm{m}^{2} / \mathrm{ha}\right)\end{array}$ & $\begin{array}{c}\mathrm{DR} \\
(\%)\end{array}$ & $\begin{array}{c}\text { INP } \\
(\%)\end{array}$ \\
\hline Alstonia scholaris & 2 & 0,5 & 5,56 & 2,5 & 2,85 & 0,096 & 2,2 & 10,61 \\
Archidendron pauciflorum & 3 & 0,5 & 5,56 & 3,75 & 4,28 & 0,029 & 0,51 & 10,36 \\
Artocarpus anisophyllus & 5 & 0,75 & 8,33 & 6,25 & 7,14 & 0,212 & 5,19 & 20,67 \\
Artocarpus elasticus & 4 & 0,25 & 2,78 & 5 & 5,71 & 0,126 & 3 & 11,49 \\
Artocarpus integer & 6 & 0,5 & 5,56 & 7,5 & 8,57 & 0,055 & 1,27 & 15,39 \\
Dimocarpus longan & 6 & 0,75 & 8,33 & 7,5 & 8,57 & 0,049 & 1,02 & 17,92 \\
Durio zibethinus & 12 & 0,75 & 8,33 & 15 & 17,14 & 0,194 & 4,71 & 30,18 \\
Garcinia parvifolia & 1 & 0,25 & 2,78 & 1,25 & 1,42 & 0,0093 & 0,23 & 4,44 \\
Hevea braziliensis & 9 & 1 & 11,11 & 11,25 & 12,85 & 1,716 & 41,47 & 65,44 \\
Hopea sangal & 5 & 0,5 & 5,56 & 6,25 & 7,14 & 0,071 & 1,84 & 14,54 \\
Nephelium lappaceum & 3 & 0,5 & 5,56 & 3,75 & 4,28 & 0,024 & 0,69 & 10,53 \\
Parkia speciosa & 2 & 0,5 & 5,56 & 2,5 & 2,85 & 0,035 & 0,92 & 9,34 \\
Shorea bracteolata & 3 & 0,75 & 8,33 & 3,75 & 4,28 & 0,288 & 6,86 & 19,48 \\
Shorea leprosula & 5 & 0,5 & 5,56 & 6,25 & 7,14 & 0,053 & 1,3 & 14,002 \\
Shorea macrophylla & 3 & 0,75 & 8,33 & 3,75 & 4,28 & 1,183 & 28,57 & 41,19 \\
Syzygium malaccense & 1 & 0,25 & 2,78 & 1,25 & 1,42 & 0,0068 & 0,15 & 4,35 \\
\hline Jumlah & 70 & 9 & 100 & 87,5 & 100 & 4,138 & 100 & 300 \\
\hline Kun & 5 & & &
\end{tabular}

Keterangan: F : Frekuensi, FR : Frekuensi Relatif, K : Kerapatan, KR : Kerapatan Relatif, D : Dominansi, DR : Dominansi Relatif, INP : Indeks Nilai Penting

Komposisi jenis pada tingkat tiang ditemukan ada 18 spesies dengan total 94 individu. Nilai kerapatan tertinggi yaitu ditemukan pada Hevea braziliensis dengan kerapatan 200 ind/ha, Nephelium lappaceum yaitu 45 ind/ha, Artocarpus integer dan Lansium domesticum masing-masing nilai kerapatannya yaitu 25 ind/ha (Tabel 5).

Tabel 5 Komposisi Vegetasi pada Tingkat Tiang Agroekosistem Karet di Desa Nanga Pemubuh

\begin{tabular}{lcccccccc}
\hline \multicolumn{1}{c}{ Spesies } & $\begin{array}{c}\text { Jumlah } \\
\text { individu }\end{array}$ & $\mathrm{F}$ & $\begin{array}{c}\mathrm{FR} \\
(\%)\end{array}$ & $\begin{array}{c}\mathrm{K} \\
\text { (ind/ha) }\end{array}$ & $\begin{array}{c}\mathrm{KR} \\
(\%)\end{array}$ & $\begin{array}{c}\mathrm{D} \\
\left(\mathrm{m}^{2} / \mathrm{ha}\right)\end{array}$ & $\begin{array}{c}\mathrm{DR} \\
(\%)\end{array}$ & $\begin{array}{c}\mathrm{INP} \\
(\%)\end{array}$ \\
\hline Areca catechu & 2 & 0,25 & 3,03 & 10 & 2,12 & 0,012 & 0,21 & 5,37 \\
Arenga pinnata & 1 & 0,25 & 3,03 & 5 & 1,06 & 0,066 & 1,13 & 5,23 \\
Artocarpus anisophyllus & 3 & 0,25 & 3,03 & 15 & 3,19 & 0,017 & 0,29 & 6,51 \\
Artocarpus integer & 5 & 0,75 & 9,09 & 25 & 5,31 & 0,12 & 2,11 & 16,52 \\
Bellucia axinanthera & 2 & 0,25 & 3,03 & 10 & 2,12 & 0,016 & 0,29 & 5,44 \\
Dimocapus longan & 4 & 0,25 & 3,03 & 20 & 4,25 & 0,017 & 0,3 & 7,59 \\
Durio zibethinus & 4 & 0,75 & 9,09 & 20 & 4,25 & 0,038 & 0,65 & 13,99 \\
\hline
\end{tabular}

Tabel 5. Komposisi Vegetasi pada Tingkat Tiang Agroekosistem Karet di Desa Nanga Pemubuh 


\begin{tabular}{lcccccccc}
\hline \multicolumn{1}{c}{ Spesies } & $\begin{array}{c}\text { Jumlah } \\
\text { individu }\end{array}$ & $\mathrm{F}$ & $\begin{array}{c}\mathrm{FR} \\
(\%)\end{array}$ & $\begin{array}{c}\mathrm{K} \\
(\mathrm{ind} / \mathrm{ha})\end{array}$ & $\begin{array}{c}\mathrm{KR} \\
(\%)\end{array}$ & $\begin{array}{c}\mathrm{D} \\
\left(\mathrm{m}^{2} / \mathrm{ha}\right)\end{array}$ & $\begin{array}{c}\mathrm{DR} \\
(\%)\end{array}$ & $\begin{array}{c}\mathrm{INP} \\
(\%)\end{array}$ \\
\hline Garcinia parvifolia & 1 & 0,25 & 3,03 & 5 & 1,06 & 0,0075 & 0,13 & 4,22 \\
Hevea brasilliensis & 40 & 1 & 12,12 & 200 & 42,52 & 2,27 & 39,07 & 93,75 \\
Hopea sangal & 2 & 0,5 & 6,06 & 10 & 2,12 & 0,017 & 0,29 & 8,48 \\
Lansium domesticum & 5 & 0,25 & 3,03 & 25 & 5,31 & 0,033 & 0,57 & 8,92 \\
Macaranga tanarius & 4 & 0,5 & 6,06 & 20 & 4,25 & 2,5 & 42,95 & 53,27 \\
Mangifera minor & 3 & 0,5 & 6,06 & 15 & 3,19 & 0,015 & 0,26 & 9,51 \\
Nephelium lappaceum & 9 & 0,75 & 9,09 & 45 & 9,57 & 0,4 & 6,86 & 25,53 \\
Parkia speciosa & 1 & 0,25 & 3,03 & 5 & 1,06 & 0,0009 & 0,017 & 4,11 \\
Shorea bracteolata & 1 & 0,25 & 3,03 & 5 & 1,06 & 0,1 & 1,72 & 5,81 \\
Shorea leprosula & 5 & 0,75 & 9,09 & 25 & 5,31 & 0,164 & 2,82 & 17,23 \\
Shorea macrophylla & 2 & 0,5 & 6,06 & 10 & 2,12 & 0,014 & 0,24 & 8,43 \\
\hline Jumlah & 94 & 8,25 & 100 & 470 & 100 & 5,83 & 100 & 300 \\
\hline Kun
\end{tabular}

Keterangan: F : Frekuensi, FR : Frekuensi Relatif, K : Kerapatan, KR : Kerapatan Relatif, D : Dominansi, DR : Dominansi Relatif, INP : Indeks Nilai Penting

Tingkat pancang memiliki komposisi jenis ada 18 jenis dengan total 164 individu. Nilai kerapatan tertinggi adalah pada Hevea braziliensis dengan kerapatan 1260 ind/ha, kemudian Durio zibethinus yaitu $420 \mathrm{ind} / \mathrm{ha}$, dan Bellucia axinanthera yaitu $260 \mathrm{ind} / \mathrm{ha}$ (Tabel 6).

Tabel 6 Komposisi Vegetasi pada Tingkat Pancang Agroekosistem Karet di Desa Nanga Pemubuh

\begin{tabular}{|c|c|c|c|c|c|c|}
\hline Spesies & $\begin{array}{c}\text { Jumlah } \\
\text { individu }\end{array}$ & $F$ & $\begin{array}{l}\text { FR } \\
(\%)\end{array}$ & $\begin{array}{c}\mathrm{K} \\
\text { (ind/ha) }\end{array}$ & $\begin{array}{l}\mathrm{KR} \\
(\%)\end{array}$ & $\begin{array}{l}\text { INP } \\
(\%)\end{array}$ \\
\hline Eurycoma longifolia & 2 & 0,5 & 5,55 & 40 & 1,219 & 3,99 \\
\hline Bellucia axinanthera & 13 & 0,75 & 8,33 & 260 & 7,926 & 16,26 \\
\hline Nephelium lappceum & 8 & 0,5 & 5,55 & 160 & 4,878 & 10,43 \\
\hline Parkia speciosa & 5 & 0,5 & 5,55 & 100 & 3,048 & 8,6 \\
\hline Calamus sp. & 12 & 0,5 & 5,55 & 240 & 7,317 & 12,87 \\
\hline Dracaena & 10 & 0,5 & 5,55 & 200 & 6,097 & 11,65 \\
\hline Macaranga tanarius & 4 & 0,5 & 5,55 & 80 & 2,439 & 7,99 \\
\hline Bambusa tuldoides & 2 & 0,5 & 5,55 & 40 & 1,219 & 6,77 \\
\hline Hevea brasilliensis & 63 & 1 & 11,11 & 1260 & 38,414 & 49,52 \\
\hline Durio zibethinus & 21 & 0,75 & 8,33 & 420 & 12,804 & 21,13 \\
\hline Shorea leprosula & 5 & 0,25 & 2,77 & 100 & 3,048 & 5,82 \\
\hline Lansium domesticum & 7 & 0,75 & 8,33 & 140 & 4,268 & 12,6 \\
\hline Syzygium malaccense & 1 & 0,25 & 2,77 & 20 & 0,609 & 3,38 \\
\hline Dillenia indica & 1 & 0,25 & 2,77 & 20 & 0,609 & 3,38 \\
\hline Artocarpus elasticus & 2 & 0,5 & 5,55 & 40 & 1,219 & 3,99 \\
\hline Artocarpus integer & 4 & 0,25 & 2,77 & 80 & 2,439 & 7,99 \\
\hline Dimocarpus longan & 2 & 0,25 & 2,77 & 40 & 1,219 & 3,99 \\
\hline Alstonia scholaris & 2 & 0,5 & 5,55 & 40 & 1,219 & 3,99 \\
\hline Jumlah & 164 & 9 & 100 & 3280 & 100 & 300 \\
\hline
\end{tabular}

Keterangan: F : Frekuensi, FR : Frekuensi Relatif, K : Kerapatan, KR : Kerapatan Relatif, D : Dominansi, DR : Dominansi Relatif, INP : Indeks Nilai Penting

Indeks Nilai Penting, Indeks dominansi(C), Indeks keanekaragaman (H') dan Indeks Kemerataan Jenis (E') di Kawasan Agroekosistem Karet di Desa Pemubuh

Komposisi regenerasi tegakan pada kawasan agroekosistem karet di Desa Nanga Pemubuh Kecamatan Sekadau Hulu Kabupaten Sekadau dilihat dari indeks nilai penting (INP) untuk tingkat pohon dominan (INP>10\%) yaitu ditemukan pada spesies Hevea braziliensis $(65,44 \%)$, Durio zibethinus $(46,50 \%)$ dan Shorea macrophylla $(41,19 \%)$.Tingkat tiang untuk indeks nilai penting (INP) yang dominan Hevea braziliensis (93,75\%), Macaranga tanarius (53.27\%) dan Nephelium lappaceum $(25,53) \%$. Indeks nilai penting (INP) dominan pada tingkat pancang ditemukan pada Hevea braziliensis (49,2\%), Durio zibethinus $(21,13 \%)$, dan Belucia axinanthera $(16,26 \%)$ (Tabel 7) 
Tabel 7 Indek Nilai Penting ( INP) untuk masing-masing tingkat tegakan jenis yang dominan (INP>10\%)

\begin{tabular}{cccc}
\hline Tingkat regenerasi & & Tingkat regenerasi & Indeks Nilai Penting (INP) (\%) \\
\hline Pohon & 1. & Hevea braziliensis & 65,44 \\
& 2. & Shorea macrophylla & 41,19 \\
& 3. & Durio zibethinus & 30,18 \\
& 4 & Artocapus anisophylus & 20,67 \\
Tiang & 5. & Shorea bracteolata & 19,48 \\
& 1. & Hevea braziliensis & 93,75 \\
& 2. & Macaranga tanarius & 53,27 \\
& 3. & Nephelium lappaceum & 25,53 \\
Pancang & 4. & Shorea leprosula & 17,23 \\
& 5. & Artocarpus integer & 16,52 \\
& 1. & Hevea braziliensis & 49,52 \\
& 2. & Durio zibethinus & 21,13 \\
& 3. & Bellucia axinanthera & 16,26 \\
& 4. & Calamus sp. & 12,87 \\
& 5. & Lansium domesticum & 12,60 \\
\hline
\end{tabular}

Indeks dominansi $(\mathrm{C})$, indeks keanekaragaman (H') dan indeks kemerataan jenis (E') di kawasan agroekosistem karet Desa Pemubuh berdasarkan hasil analisis yaitu indeks dominansi (C) pada tingkat pohon adalah 0,107 , tingkat tiang 0,119 , dan tingkat pancang 0,247. Nilai indeks keanekaragaman (H') pada tingkat pohon adalah 2,339, tingkat tiang 2,294, dan tingkat pancang 1,652. Indeks kemerataan jenis (E') untuk tingkat pohon adalah 0,941 , tingkat tiang adalah 0,923 , dan tingkat pancang 0,794 (Tabel 8).

Tabel 8. Tabel indeks dominansi (C), indeks keanekaragaman (H') dan indekskemerataan jenis (E') di kawasan agroekosistem karet Desa Nanga Pemubuh

\begin{tabular}{lccc}
\hline \multicolumn{1}{c}{ Tingkat regenerasi } & Indeks dominansi (C) & Indeks keanekaragaman (H') & Indeks kemerataan (E') \\
\hline Pohon & 0,107 & 2,339 & 0,941 \\
Tiang & 0,119 & 2,294 & 0,923 \\
Pancang & 0,247 & 1,652 & 0,794 \\
\hline
\end{tabular}

\section{Faktor Fisika dan Kimia Lingkungan di Kawasan Agroekosistem Karet}

Faktor fisika dan kimia lingkungan di kawasan agroekosistem karet di Desa Nangaa Pemubuh yang diukur adalah suhu udara, kelembaban tanah, kelembaban udara, Intensitas cahaya dan $\mathrm{pH}$ tanah (Tabel 9).

Tabel 9 Faktor fisika dan kimia lingkungan

\begin{tabular}{cccccc}
\hline Parameter lingkungan & Satuan & \multicolumn{5}{c}{ Lokasi } \\
\cline { 3 - 6 } & & 1 & 2 & 3 & 4 \\
\hline Suhu & ${ }^{\circ} \mathrm{C}$ & 29 & 32 & 30 & 31 \\
Kelembaban tanah & $\%$ & 30 & 30 & 30 & 30 \\
Kelembaban udara & $\%$ & 70 & 71 & 70 & 70 \\
Intensitas cahaya & lux & 315 & 520 & 532 & 290 \\
pH tanah & - & 4,9 & 4,5 & 4,5 & 4,5
\end{tabular}

Keterangan: Lokasi 1 (Dusus Emperarak); Lokasi 2 (Dusun Sepanjang); Lokasi 3 (Dusun Natai Ilong);

Lokasi 4 (Tembawang Hangu)

\section{Pembahasan}

Berdasarkan hasil identifikasi dan pengamatan yang dilakukan pada kawasan agroekosistem di Desa Nanga Pemubuh Kecamatan Sekadau Hulu Kabupten Sekadau ditemukan 36 jenis, dikelompokan kedalam 33 genus dan 23 famili. Tingkat regenerasi vegetasi yang ditemukan yaitu pada tingkat pohon 16 jenis, tiang 17 jenis, pancang 18 jenis, dan semai 16 jenis. Hasil ini lebih rendah bila dibandingkan dengan hasil penelitian Ripin et al., (2015) di Kabupaten Sanggau yaitu 93 spesies dikelompokkan ke dalam 34 famili yang teridentifikasi, dengan komposisi pohon 49 jenis, tiang 28 jenis, pancang 41 jenis semai 55 jenis.

Berdasarkan Tabel 2 jumlah famili vegetasi yang ditemukan, famili yang paling mendominasi di kawasan Desa Nanga Pemubuh pada semua tingkat pertumbuhan terdiri dari 3 famili yaitu famili Arecaceae, Dipterocaearpace, dan Moraceae 
dengan jumlah masing-masing terdiri dari 4 jenis. Arecaceae dengan jumlah 4 jenis yaitu Areca catechu, Arenga pinnata, Calamus sp., dan Korthalsia flagellaris. Famili Dipterocaearpace terdiri dari 4 jenis yaitu Shorea bracteolata, Shorea leprosula, Shorea macrophylla, dan Hopea sangal. Kemudian famili Moraceae terdiri dari 4 jenis yaitu Artocarpus anisophyllus, Artocarpus elasticus, Ficus sp., dan Artocarpus integer. Yusuf (2005) menyatakan bahwa anggota dari famili Euphorbiaceae dikenal memiliki kemampuan untuk beradaptasi di berbagai tipe hutan tropik.

Komposisi jenis pada tingkat pohon ada 16 spesies dengan total 70 individu. Kerapatan vegetasi pada tingkat di kawasan agroekosistem karet di Desa Nanga Pemubuh berdasarkan 16 spesies berkisar antara 1,25-11,25 ind/ha, dengan nilai kerapatan total sebesar 87,5 ind/ha (Tabel 4.3). Nilai kerapatan tertinggi yaitu Durio zibethinus (15 ind/ha), kemudian Hevea braziliensis (11,25 ind/ha), Artocarpus integer dan Dimocarpus longan, masing-masing memliki nilai kerapatan 7,5 ind/ha. Nilai dominansi tertinggi yaitu pada Hevea braziliensis dengan nilai dominansi adalah $1,716 \mathrm{~m}^{2} /$ ha (Tabel 4). Tingginya jenis karet (Hevea braziliensis) ini disebabkan budidaya tanaman oleh masyarakat setempat secara turun-temurun sehingga tanaman karet menjadi dominan. Selain itu juga karet lokal merupakan sumber ekonomi utama masyarakat tersebut sehingga keberadaan karet (Hevea braziliensis) tetap terjaga. Smith (1977) mengemukakan bahwa jenis yang dominan adalah jenis yang dapat memanfaatkan lingkungan yang ditempati secara efisien dibanding jenis lain dalam tempat yang sama.

Komposisi jenis pada tingkat tiang ditemukan ada 18 spesies dengan total 94 individu. Nilai kerapatan tertinggi yaitu Hevea braziliensis dengan kerapatan $200 \mathrm{ind} / \mathrm{ha}$, Nephelium lappaceum yaitu $45 \mathrm{ind} / \mathrm{ha}$, Artocarpus integer dan Lansium domesticum masing-masing nilai kerapatannya yaitu $25 \mathrm{ind} / \mathrm{ha}$ (Tabel 5). Tingkat pancang memiliki komposisi jenis ada 18 jenis dengan total 164 individu. Nilai kerapatan tertinggi adalah pada Hevea braziliensis dengan kerapatan 1260 ind/ha, kemudian Durio zibethinus yaitu 420 ind/ha, dan Bellucia axinanthera yaitu $260 \mathrm{ind} / \mathrm{ha}$ (Tabel 6). Soerianegara \& Indrawan (2002), menyebutkan bahwa tumbuhan mempunyai korelasi yang sangat nyata dengan tempat tumbuh (habitat) dalam hal penyebaran jenis, kerapatan, dan dominansi.
Komposisi regenerasi tegakan pada kawasan agroekosistem karet di Desa Nanga Pemubuh Kecamatan Sekadau Hulu Kabupaten Sekadau dilihat dari indeks nilai penting (INP) untuk tingkat pohon dominan (INP > 10\%) yaitu ditemukan pada spesies Hevea braziliensis $(65,44 \%)$, Durio zibethinus $(46,50 \%)$ dan Shorea macrophylla $(41,19 \%)$. Tingkat tiang untuk indeks nilai penting (INP) yang dominan Hevea braziliensis $(93,75 \%)$, Macaranga tanarius (53.27\%) dan Nephelium lappaceum $(25,53) \%$. Indeks nilai penting (INP) dominan pada tingkat pancang ditemukan pada Hevea braziliensis (49,2\%), Durio zibethinus $(21,13 \%)$, dan Belucia axinanthera $(16,26 \%)$ (Tabel 7). Menurut Sutisna (1981), suatu jenis dikatakan berperan untuk tingkat tiang dan pohon jika INP $>15 \%$. Bisa diperkirakan bahwa spesies Hevea braziliensis, Durio zibethinus, Shorea macrophylla, Macaranga tanarius, dan Nephelium lappaceumadalah spesies-spesies yang berperan penting di kawasan agroekosistem karet di Desa Nanga Pemubuh. Menurut Fachrul (2006), jenis vegetasi yang memiliki nilai (INP) tertinggi, maka jenis itu sangat mempengaruhi kestabilan ekosistem tersebut.

Berdasarkan Tabel 8 indeks kemerataan jenis (E') pada kawasan agroekosistem karet di Desa Nanga Pemubuh berkisar 0,794-0,941 untuk tiap tingkat tegakan regenerasi. Tingkat pohon adalah 0,941, tingkat tiang adalah 0,923 , dan tingkat pancang 0,794. Hal ini menunjukkan bahwa komunitas tanaman pada tiap tingkat tegakan tidak didominasi oleh jenis tanaman tertentu saja, melainkan tersebar oleh jenis-jenis yang lain. Arrijani (2008) menyatakan bahwa nilai kemerataan jenis ditentukan oleh distribusi jenis pada kawasan secara merata. Selain itu menurut Odum (1993) menyatakan bahwa semakin tinggi nilai E', maka keragaman jenis dalam komunitas semakin stabil.

Hasil analisis indeks dominansi (C) pada tingkat pohon adalah 0,107 , tingkat tiang 0,119 , dan tingkat pancang 0,247 . Hal ini menunjukan bahwa tingkat pertumbuhan yang berlangsung dengan normal yaitu dengan kondisi tingkat pancang lebih besar dari tingkat tiang, dan tingkat tiang lebih besar dari tingkat pohon. Menurut Indriyanto (2006), proses pertumbuhan vegetasi dinyatakan berjalan dengan baik apabila terdapat perbedaan tingkat pada masing-masing tingkat tegakan pertumbuhan vegetasi. 
Struktur vegetasi dilihat dari nilai indeks keanekaragaman (H') pada kawasan agroekosistem karet di Desa Nanga Pemubuh berbeda tiap regenerasi tegakannya. Indeks keanekaragaman tingkat pohon adalah 2,339, tingkat tiang 2,294, dan tingkat pancang 1,652. Hal ini menunjukan bahwa nilai indeks keanekaragaman $\left(\mathrm{H}^{\prime}\right)$ pada kawasan agroekosistem karet di Desa Nanga Pemubuh tergolong sedang atau komunitas pada kawasan stabil. Menurut Kuswandi, (2015) nilai indeks keanekaragaman jenis (H') digunakan untuk mengetahui tingkatkestabilan keanekaragaman jenis. Kawasan yang memiliki nilai $H^{\prime}<1,5$ dikatakan komunitas kurang stabil, apabila nilai H' antara 1,5-3,5 dikatakan komunitas stabil, dan jika nilai $\mathrm{H}^{\prime}>3,5$ dikatakan komunitas sangat stabil.

Berdasarkan hasil pengukuran suhu, kelembaban tanah, kelembaban udara, intensitas cahaya, dan tingkat keasaman (Tabel 9) kawasan agroekosistem karet di Desa Nanga Pemubuh memiliki suhu udara berkisar antara 29-31 ${ }^{\circ} \mathrm{C}$. Menurut Sunarjono (2000), suhu yang mendukung kehidupan suatu tumbuhan berkisar $25-35^{\circ} \mathrm{C}$. Menurut Warnock, (2010), suhu berpengaruh terhadap pertumbuhan vegetatif, perbungaan, pembentukan biji, dan pemasakan biji.

Rata-rata kelembaban tanah di kawasan agrosistem karet di Desa Nanga Pemubuhh adalah $30 \%$. Kelembaban tanah dapat berpengaruh terhadap perkembangan biji dan benih jenis-jenis tumbuhan. Kemudian kelembaban udara di kawasan agrosistem karet di Desa Nanga Pemubuh adalah berkisar antara 70-71 \%. Menurut Kurniawan \& Parikesit (2008), tumbuhan dapat hidup pada kelembaban udara 50-80\%.

Intensitas cahaya di kawasan agrosistem karet di Desa Nanga Pemubuh adalah 315-520 lux. Nilai intensitas cahaya ini masih mendukung kehidupan vegetasi yang terdapat di kawasan agrosistem karet di Desa Nanga Pemubuh. Tingkat keasaman di kawasan agrosistem karet di Desa Nanga Pemubuhh adalah (pH) 4,5-4,9. Indriyanto (2006) mengemukakan kawasan hutan hujan tropis memiliki suhu rata-rata $25^{\circ} \mathrm{C}$ dengan perbedaan temperatur yang kecil sepanjang tahun, dan kelembaban udara hingga $80 \%$. Hal ini membuat kawasan hutan hujan tropis memiliki keanekaragaman yang cukup tinggi dibandingkan kawasan lainnya.

\section{DAFTAR PUSTAKA}

Arifin, HS, Sardjona, MA, Djogo, T, Wattimena, GA, \& Widianto, 2003, Agroforestri di Indonesia, Word Agroforestry Center, Bogor

Arrijani, 2008, “Analisis Vegetasi Hulu DAS Cianjur Taman Nasional Gunung Gede Pangrango", Jurnal Biodiversitas, vol.7, no. 2, hal. 147-153

Badan Perencanaan Pembangunan Nasional (BPPN), 2003, Strategi dan Rencana Aksi Keanekaragaman Hayati Indonesia 2003-2020, Jakarta

Badan Pusat Statistik, 2015, Kalimantan Barat Dalam Angka, Badan Pusat Statistik Kalimantan Barat

Badan Pusat Statistik, 2014, Kecamatan Sekadau Hulu, Sekadau, Kabupaten Sekadau

Dasuki, UA, 1991, Sistematika Tumbuhan Tingkat Tinggi, Sekolah Tinggi Ilmu Hayati, Institut Teknologi Press, Bandung

Fachrul, M, 2006, Metode Sampling Bioekologi, Bumi Aksara, Jakarta

Indriyanto, 2006, Pengantar Budi Daya Hutan, Penerbit Bumi Aksara, Jakarta

Iyai, DA, \& Pattiselano, F, 2006, "Universitas Sebelas Maret Surakarta, Surakarta", Biodiversitas Journal Of Biological Diversity, Vol 7, No.2, hal.1-6

KEPAS (Kelompok Penelitian Agroekosistem), 1998, Pendekatan agroekosistem pada Pola Pertanian Lahan Kering Hasil Penelitian di Empat Zona Agroekosistem di Jawa Timur, Badan Penelitian dan Pengembangan Pertanian, Jakarta

Kuni, BE, Hardiansyah, G \& Idham, 2015, "Etnobotani Masyarakat Suku Dayak Kerabat di Desa Tapang Perodah Kecamatan Sekadau Hulu Kabupaten Sekadau", Jurnal Hutanlestari, vol. 3, no. 3, hal. 383-400

Kurniawan, A \& Parikesit, 2008, "Persebaran jenis pohon di sepanjang faktor lingkungan di Cagar Alam Pananjung Pangandaran”, Jawa Barat. Biodiversitas, vol. 9, no. 4, hal. 275-279

Kuswandi, B, 2015, "Smart packaging: sensors for monitoring of food quality and safety”, Sensing and Instrumentation for Food Quality and Safety, vol. 5, no. 1, hal. 137-146 
Odum, EP, 1993, Dasar-Dasar Ekologi, Yogjakarta, Gajah Mada University

Rafdinal \& Pitopang, R, 2019, "The phytososiological of agroforestry Tembawang at secundary forest Sekadau Hulu West Kalimantan Indonesia “, Journal of Physics, vol.1242, no. 012041, hal. 1-7

Ripin, Astiani, D \& Latifah,S, 2015, "Keanekaragaman dan Potensi Jenis Vegetasi Penyusun Hutan TembawangAmpar di Desa Cempedak Kecamatan Tayan Hilir Kabupaten Sanggau", Jurnal Hutan Lestari, vol. 1, no. 1, hal. 1-6

Smith, SLS, 1977, Tourism Analysi, A Handbook, Harlow Longman Group, England

Soerianegara, I \& Indrawan, A, 1988, Ekologi Hutan Indonesia, Laboratorium Ekologi Hutan, Fakultas Kehutanan, Institut Pertanian Bogor, Bogor

Soerianegara, I \& Indrawan, A, 2002, Ekologi Hutan Indonesia, Laboratorium Ekologi Hutan, Fakultas Kehutanan, Institut Pertanian Bogor, Bogor
Steenis, V, 2005, Flora, Pradnya Paramita, Jakarta

Suin, NM, 2002, Metoda Ekologi, Penerbit Universitas Andalas, Padang

Sumarhani \& Kalima, T, 2015, "Struktur dan Komposisi Vegetasi Agroforestri Tembawang di Kabupaten Sanggau", ProsSemNasMasy Biodiv Indon, vol. 1, no. 5, hal. 1099-1104

Sunarjono, 2000, Prospek Tanaman Buah, Penebar Swadaya, Jakarta

Sutisna, U, 1981, Komposisi jenis hutan bekas tebangan di Batulicin, Kalimantan Selatan, Deskripsi dan Analisis, Balai Penelitian Hutan, Bogor

Warnock, M, 2010, Special educational needs, a new look, Continuum, London

Yusuf, AM, 2005, Metodologi Penelitian (Dasar-Dasar Penyelidikan Ilmiah), UNP Press, Padang 